\title{
ON THE SIDE OF THE WOLF
}

\author{
by Robert C. Guest, 10989-126 Street, Edmonton, Alberta
}

On March 15, 1967, the Legislative Committee of Tourism and Natural Resources in Ontario recommended higher bounties on timber wolves with the avowed aim of drastically reducing the wolf population. Wolves in Algonquin Provincial Park would be killed.

This move was of particular interest to me because of a wolf conservation project that I've been working on for over a year. I have designed a "wolf conservation" trademark, or symbol,

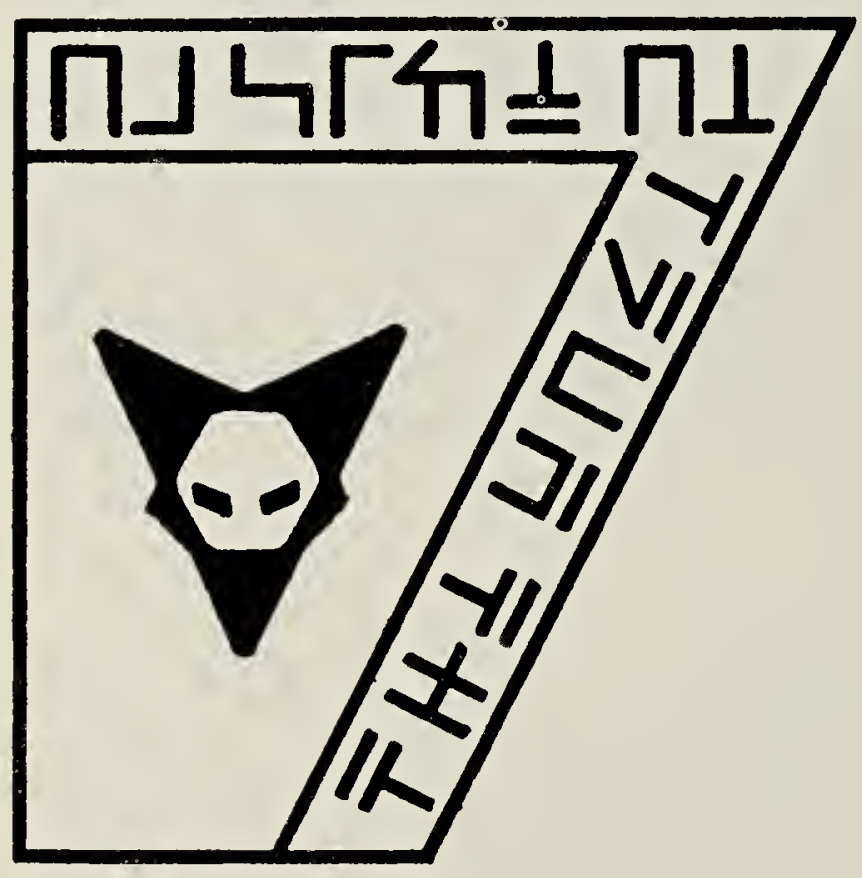

and have finally succeeded in having this propertly registered in Ottawa. I believe that the wolf has a biological value and that this has been proven time and again but also the wolf has an aesthetic value which is equally valid and permanent. What would the great outdoors be like without the wolf?

Naturally I wrote on the side of the wolf and against the recommendation. I was pleased to learn later that the recommendation had raised a storm of protest all across Canada. Thousands of letters were sent to the Honourable John P. Roberts, Q.C., Prime Minister of Ontario and to the Hon. Rene Brunelle, Minister of Lands and Forests.

On April 10 the Hon. Rene Brunelle made a statement in the Legislature rejecting the totally unrealistic demands of the committee. The government already has 25 specially trained predaitor control officers and they assist farmers or trappers wherever predators cause damage. The wolf will continue to be controlled in Ontario but it will not be exterminated.

\section{SULPHUR BUTTERFLIES AT THE PAS, MANITOBA}

\author{
by Walter V. Krivda, The Pas
}

There are two kinds of yellow butterflies that may be seen flying over cultivated fields, especially clover and alfalfa. These are the yellow sulphur and the orange sulphur. The yellow species is Colias philodice and the orange is Colias eurytheme. Of the two species, the yellow is generally the more common.

The orange sulphur feeds in the caterpillar stage on alfalfa. It is said to be a recent arrival and it may become more common as the acreage of alfalfa increases. However, it is believed that the orange sulphur cannot survive our severe winters. In early July a few wind-blown individuals arrive in this area. In some years the sporadic migration becomes a considerable local flight and by late 
July or August there may be many bright orange butterflies in the alfalfa fields. Further south this species may be a real pest and in the central states whole fields may be a brilliant orange with clouds of these butterflies.

The yellow sulphur overwinters in Manitoba at least as far north as The Pas. It overwinters in the pupal stage and emerges in late May or early June. This spring flight is made up of small specimens, known at kootenai, which are rather darkly marked on the underside.

By mid-August there is a second brood of the yellow sulphur on the wing, feeding at fall-blooming asters and particularly thistle flowers. Specimens of this brood are easily twice the size of the May-June brood. This autumn flight, rather constant in appearance from year to year, can be very abundant locally and fresh individuals continue to emerge through September. In mild dry autumns some will be on the wing into early October, but these are rather dwarfish specimens.

The early spring fiight of the yellow sulphur is of variable abundance and it would seem that this is dependent on the weather of the preceding autumn. A mild, long autumn may produce many pupae that survive the winter. A short, cold autumn does not permit quick larval development and the larvae are killed off by the first heavy frosts. This results in a reduced light of the dwarfish adults the following spring.

A certain amount of hybridization ccurs between the yellow and orange sulphurs. This fact has been accepted for about 70 years. The $\mathrm{F}^{1}$ are yellow with orange patches or "flushes". Various $\mathrm{F}^{2}$ and backcross individuals may occur but in an average year the pecies remain relatively pure. The calte of hybridization seems to increase with the abundance of the two species. There are areas now in the United States, Baltimore for example, where the two species are so hybridized that hey behave as one species and are known to collectors as "hybrida".

There are three other species of sulphurs that can be collected in many areas of Manitoba and Saskatchewan.

The blueberry sulphur, Colias interior, flies in late July and August in woods where blueberries are common. The caterpillars feed on the velvet-leaf blueberry, Vaccinium myrtilloides. The adults fly low to the ground and are hard to net in the shubbery.

The most remarkable and specular of our sulphurs is the giant sulphur, Colias gigantea, which flies in late June in boggy areas. The caterpillars feed on willow, likely Salix lutea, but only on young plants up to two feet tall. The caterpillars pupate at ground level and are likely covered but not apparently harmed by the snow water. The eggs are laid singly on the under side of the willow leaf. They are cream coloured and sharply pointed. Giant sulphurs are strong fliers and very wary. They are most easily collected in scrubby areas while feeding at bog flowers such as Labrador tea, Ledum groenlandicum. Males and females are a fine lemon yellow, but there is also a cream-white form of female, called alba.

The fifth species of sulphur, Colias christina, is named after the wife of a Hudson's Bay clerk of early days. Colias christina is orange and can be confused with $C$. eurytheme but it is a butterfly of wild country. The caterpillars likely feed on a species of locoweed and not on cultivated alfalfa. The flight pattern is distinct, it flies several yards and then drops down. This it does again and again. It can be easily flushed even in a high wind. It is on the wing in the first week of July at The Pas.

There are other sulphurs in the extreme northern parts of Canada. These are very rare in most collections. Across Europe and Asia and in South America still other sulphurs occur. Much work is needed to learn their food preferences and to understand their phylogenetic relationships. 